\title{
COMPRESSIBLE ANALYSIS OF INLET PLENUM PRESSURE RISE DUE TO SODIUM BOILING IN FUEL SUBASSEMBLIES DURING PUMP COASTDOWN OF AN LMFBR
}

by

Kalimullah and H. H. Hummel

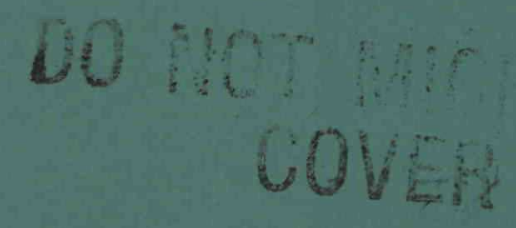

ARGONNE NATIONAL LABORATORY, ARGONNE, ILLINOIS

Prepared for the U. S. NUCLEAR REGULATORY COMMISSION under Interagency Agreement DOE 40-550-75 
The facilities of Argonne National Laboratory are owned by the United States Government. Under the terms of a contract (W-31-109-Eng-38) among the U. S. Department of Energy, Argonne Universities Association and The University of Chicago, the University employs the staff and operates the Laboratory in accordance with policies and programs formulated, approved and reviewed by the Association.

\section{MEMBERS OF ARGONNE UNIVERSITIES ASSOCIATION}

The University of Arizona

Carnegie-Mellon University

Case Western Reserve University

The University of Chicago

University of Cincinnati

Illinois Institute of Technology

University of Illinois

Indiana University

The University of Iowa

Iowa State University
The University of Kansas

Kansas State University

Loyola University of Chicago

Marquette University

The University of Michigan

Michigan State University

University of Minnesota

University of Missouri

Northwestern University

University of Notre Dame
The Ohio State University

Ohio University

The Pennsylvania State University

Purdue University

Saint Louis University

Southern Illinois University

The University of Texas at Austin

Washington University

Wayne State University

The University of Wisconsin-Madison

This report was prepared as an account of work sponsored by an agency of the United States Government. Neither the United States Government nor any agency thereof, or any of their employees, makes any warranty, expressed or implied, or assumes any legal liability or responsibility for any third party's use, or the results of such use, of any information, apparatus, product or process disclosed in this report, or represents that its use by such third party would not infringe privately owned rights.

Available from

GPO Sales Program

Division of Technical Information and Document Control

U. S. Nuclear Regulatory Commission

Washington, D.C. 20555

and

National Technical Information Service

Springfield, Virginia 22161 


\section{DISCLAIMER}

This report was prepared as an account of work sponsored by an agency of the United States Government. Neither the United States Government nor any agency Thereof, nor any of their employees, makes any warranty, express or implied, or assumes any legal liability or responsibility for the accuracy, completeness, or usefulness of any information, apparatus, product, or process disclosed, or represents that its use would not infringe privately owned rights. Reference herein to any specific commercial product, process, or service by trade name, trademark, manufacturer, or otherwise does not necessarily constitute or imply its endorsement, recommendation, or favoring by the United States Government or any agency thereof. The views and opinions of authors expressed herein do not necessarily state or reflect those of the United States Government or any agency thereof. 


\section{DISCLAIMER}

Portions of this document may be illegible in electronic image products. Images are produced from the best available original document. 


\section{DISCLAIMER}

This report was prepared as an account of work sponsored by an agency of the United States Government. Neither the United States Government nor any agency thereof, nor any of their employees, makes any warranty, express or implied, or assumes any legal liability or responsibility for the accuracy, completeness, or usefulness of any information, apparatus, product, or process disclosed, or represents that its use would not infringe privately owned rights. Reference herein to any specific commercial product, process, or service by trade name, trademark, manufacturer, or otherwise does not necessarily constitute or imply its endorsement, recommendation, or favoring by the United States Government or any agency thereof. The views and opinions of authors expressed herein do not necessarily state or reflect those of the United States Government or any agency thereof.

\section{ARGONNE NATIONAL LABORATORY \\ 9700 South Cass Avenue Argonne, Illinois 60439}

NUREG/CR-1592

ANL $-80-48$

Distribution

Code: R7

\section{COMPRESSIBLE ANALYSIS OF \\ INLET PLENUM PRESSURE RISE \\ DUE TO SODIUM BOILING IN FUEL SUBASSEMBLIES \\ DURING PUMP COASTDOWN OF AN LMFBR}

by

Kalimullah and H. H. Humme1

Applied Physics Division

NUREG/CR--1592

TI86 002703

Prepared for the Division of Reactor Safety Research

Office of Nuclear Regulatory Research

U. S. Nuclear Regulatory Commission

Washington, D. C. 20555

Under Interagency Agreement DOE 40-550-75 


\title{
COMPRESSIBLE ANALYSIS OF INLET PLENUM PRESSURE RISE \\ DUE TO SODIUM BOILING IN FUEL SUBASSEMBLIES \\ DURING PUMP COASTDOWN OF AN LMFBR
}

by

Kalimullah and H. H. Hummel

\begin{abstract}
The effect of sodium compressibility and steel elasticity on the rise in inlet plenum pressure occurring during boiling in a loss-of-flow accident in an LMFBR has been investigated using the PTA-2 code. These effects do not seem large enough to require consideration in accident analysis. The pressure rise is less for pool than for loop designs.
\end{abstract}

NRC

FIN 非

Title

A2015

Reactor Safety Modeling and Assessment 
EXECUTIVE SUMMARY . . . . . . . . . . . . . . . . . 1

I. Introduction. . . . . . . . . . . . . . . . . 3

II. Primary System Mode1. . . . . . . . . . . . . . . 3

III. Results and Discussion. . . . . . . . . . . . . . . 4 REFERENCES. . . . . . . . . . . . . . . . . 6 


\section{FIGURE}

$\underline{\text { Page }}$

1. One dimensional model of the primary system of a CRBR-sized LMFBR used in the analysis of a pressure transient due to boiling in fuel subassemblies. The circled numbers are used to locate junctions. The numbers along the pipes are their lengths in feet. For (a) the loop and (b) the pool systems, the length and inclination to horizontal of the pipe between junctions 4 and 9 are (a) $500.0 \mathrm{ft}$ and $2.304^{\circ}$,

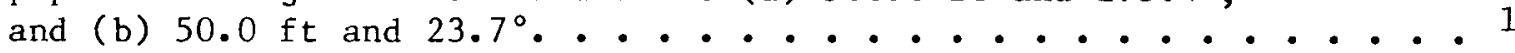

\section{TABLES}

I. Typical Features of the Primary Heat Transport System of Various Loop-Type LMFBR Designs . . . . . . . . . . . 7

II. Physical Dimensions and Initial Conditions of the 1-D Model of the Primary System of a CRBR-sized LMFBR Used in the Pressure Transient Analysis . . . . . . . . . . 8

III. Sodium Vapor Bubble Pressure-Time History Used at the Top of the Upper Axial Blanket of Core Subassemblies in the Pressure Transient Analysis . . . . . . . . . . . 9

IV. Results of Pressure Transient Analysis for the Loop Design, Elastic and Compressible Case. . . . . . . . . . 10

V. Results of Pressure Transient Analysis for the Loop Design, Rigid and Compressible Case. . . . . . . . . . . . 11

VI. Results of Pressure Transient Analysis for the Loop Design, Rigid and Incompressible Case. . . . . . . . . . . 12

VII. Results of Pressure Transient Analysis for the Pool Design, Elastic and Compressible Case. . . . . . . . . . 13

VIII. Results of Pressure Transient Analysis for the Poo1 Design, Rigid and Compressible Case. . . . . . . . . . . 14

IX. Results of Pressure Transient Analysis for the Pool Design, Rigid and Incompressible Case. . . . . . . . . . 15 
EXECUTIVE SUMMARY

The rise of inlet plenum pressure in an LMFBR because of sodium boiling and consequent downward sodium slug ejection can have an important inhibiting effect on the velocity of such ejection, which might in turn have an important effect on an accident sequence. In the SAS code compressibility of the sodium in the inlet plenum is used to smooth pressure fluctuations in calculating the coupling of the in-core sodium flow to the sodium flow in the primary loop. It seemed to be of interest to investigate whether sodium compressibility and structural elasticity effects are of real physical importance in accident calculations.

These effects have been investigated using the one-dimensional Pressure Transient Analysis Code PTA-2, using a single channel to model the core. The reactor model used was based on the CRBR, with the geometrical elevations and dimensions taken from the CRBR design. The free sodium surfaces in the reactor and pump vessels have been explicitly modeled. In addition to the loop-type CRBR design, a pool-type reactor has been simulated by using a pipe length between the pump outlet and the inlet plenum of $50 \mathrm{ft}$ rather than $500 \mathrm{ft}$. The initial coolant flow and the bubble pressure-time history data input to the analysis were based on a SAS-3A calculation of a loss of flow accident for the CRBR reported earlier.

It was found that the inlet plenum pressure buildup in the loop case was considerably larger than that in the pool case, implying an important difference in the retarding effect of the pressure buildup. This difference was caused by the difference in inertia effect of the two different liquid lengths in the inlet pipe. In either case the effect of sodium compressibility and steel elasticity on the inlet plenum pressure itself was small. For the loop case, however, the pressure difference between core and inlet plenum was considerably greater when these effects were taken into account, resulting in an increase by about a factor of two in lower sodium slug ejection rate (from $1.5 \mathrm{ft} / \mathrm{sec}$ to $3.1 \mathrm{ft} / \mathrm{sec})$. However, this ejection velocity was still small compared to that in the pool case (approximately $14.3 \mathrm{ft} / \mathrm{s}$ and insensitive to compressibility and elasticity effects). It does not appear that these effects are large enough to require consideration in accident analysis, although it would be desirable to carry out PTA-2 calculations in which the core is modeled by two or more channels with different pressure-time curves to see if the effects are larger with such a treatment. 
" 


\author{
Compressible Analysis of Inlet Plenum \\ Pressure Rise Due to Sodium Boiling in Fuel \\ Subassemblies During Pump Coastdown of an LMFBR
}

Kalimullah and H. H. Hummel

\title{
I. Introduction
}

The rise of inlet plenum pressure due to sodium boiling in the fuel subassemblies during the pump coastdown accident analysis of an LMFBR can have an important effect on the course of the accident because of the possible inhibiting effect on downward sodium slug ejection and the consequent reduction in sodium voiding ramp rate. Since the bubble pressure rises quite fast (in SAS calculations the bubble pressures in different channels rise from 2-4 atm to $10-30 \mathrm{~atm}$ in $200-400 \mathrm{msec}$ ), the effects of liquid sodium compressibility and structural material elasticity (piping, hex-can, etc.) have been investigated in the present analysis. In the SAS code compressibility of the sodium in the inlet plenum is used to smooth pressure fluctuations in calculating the coupling of the in-core sodium flow to the sodium flow in the primary loop. It seemed to be of interest to investigate whether sodium compressibility and structural elasticity effects are of real physical importance in accident calculations. Calculations have been carried out using the one-dimensional Pressure Transient Analysis code PTA-2 (based on the method of characteristics) ${ }^{1}, 2$ for a loop design and a pool design. For comparison purposes, both designs are CRBR-sized and differ only in the length of the pipe between the pump vessel outlet and lower plenum inlet (the pipe between junctions 9 and 4 in Fig. 1), $500 \mathrm{ft}$ for the loop design (a typical value as shown in Table I) and $50 \mathrm{ft}$ for the pool design.

\section{Primary System Mode1}

Figure 1 is a line diagram of the one-dimensional model used in the analysis and Table II gives the physical dimensions and initial coolant pressures and velocities of the components in the primary system. The geometrical elevations and dimensions have been taken from the CRBR design and the free surfaces of sodium in the reactor vessel and the pump vessel have been explicitly modeled. The initial coolant flow and the bubble pressure-time history data input to this analysis are based on a SAS-3A calculation of a loss of flow accident for the CRBR reported earlier ${ }^{3}$ (the particular case assuming static sodium film on cladding, no axial feedback and with clad motion). In the SAS-3A calculation 10 channels were used to model the core subassemblies, but these channels have been averaged to one core channel in the pressure transient analysis because of the limited number of pressure sources allowed in the PTA-series of codes (one pressure source allowed in PTA-1 and two in PTA-2). The steady-state coolant velocities in the averaged core channel, the bypass channel (the pipe between junctions 3 and 1 in Fig. 1) and the pipe between the pump outlet and the inlet nozzle are $18.5,5.0$ and $23.0 \mathrm{ft} / \mathrm{sec}$. The surface roughnesses of the core and bypass channels used in the pressure transient analysis have been adjusted to obtain the steady-state frictional pressure drop equal to that in the SAS-3A calculation, i.e. 81.5 psi. The roughness of the pipe between the pump outlet and inlet nozzle has been adjusted 
to obtain a steady-state frictional pressure drop of 25 psi (see Table I) for the loop design and 15 psi for the pool design (in an actual pool design a large part of this 15 psi pressure drop takes place in flow restrictors used in the pipe and the inlet plenum). The roughness of the pipe between outlet nuzzle and pump vessel inlet has also been adjusted to obtain the steady-state flow from the $8 \mathrm{ft}$ (based on CRBR design) of driving head between the two free surfaces.

The zero time of the pressure transient analysis refers to $18.34 \mathrm{sec}$ after beginning of flow coastdown (i.e., $18.34 \mathrm{sec}$ of the SAS-3A calculation) when the sodium velocity in the pipe between the pump and the inlet plenum has decreased to $4.85 \mathrm{ft} / \mathrm{sec}$, i.e. $21.1 \%$ of the steady-state value, and the pump head has decayed to $4.8 \%$ of its steady-state value. All the SAS-3A channels start boiling before this time or within $20 \mathrm{msec}$ after this time, and furthermore, most of the bubble pressure rise (shown in Table III) happens after this time. The initial pressures and velocities shown in Table II (which form the initial conditions for the pressure transient analysis) have been taken from the SAS-3A calculation. The step rise in initial pressure at junction 10 (see Fig. 1) given in Table II is due to the pump head, $5.5 \mathrm{psi}(4.8 \%$ of the steady-state head of $113.8 \mathrm{psi}$ ) for the loop design and $5.0 \mathrm{psi}(4.8 \%$ of the steady-state head of $103.8 \mathrm{psi}$ ) for the pool design. The bubble pressure-time history shown in Table III is the channel-averaged pressure of the lowest bubbles which retard the lower liquid slug in the channels. This pressure source is assumed to act at the top of the upper blanket in the core channel (see Fig. 1) in the pressure transient analysis. The pressure of the lowest bubble has been used to be more accurate in the lower liquid slug velocity calculation (than in the upper liquid slug velocity calculation) because the course of the accident (core voiding, dry-out, clad melting, etc.) is more sensitive to the lower liquid slug motion.

The pipe wall thickness for the subassembly length containing fuel pins (the pipes between junctions 8 and 7 in Fig. 1) given in Table II has been obtained from the subassembly can wall thickness ( 0.12 inch) by correcting for the presence of fuel pins (the pins are assumed to be rigid inclusions) by a multiplicative factor ${ }^{2}$, flow area inside the can/gross area inside the can $\left(6.7 \mathrm{in}^{2} / 16.3 \mathrm{in}^{2}\right)$. Since the subchannel hydraulic diameter rather than the equivalent diameter of the gross area inside the can is input as the pipe diameter, the above corrected wall thickness is further multiplied by the factor, subchannel hydraulic diameter/equivalent diameter of the gross area inside the can, so that the elastic wave speed is properly calculated. All the structural material is taken to be stainless steel 314 , and the whole system is assumed to remain at a uniform temperature of $700^{\circ} \mathrm{F}$ during the transient.

\section{Results and Discussion}

For each primary system design, three PTA-2 calculations have been made: (1) assuming the liquid sodium to be compressible and all the structural material to be elastic, (2) assuming sodium to be compressible and all the structural material to be rigid, and (3) assuming sodium to be incompressible (bulk modulus made 12.5 times too high) and all the structural material to be rigid. Tables IV to VI give the results for the loop design and Tables VII to IX give the results for the pool design. The differences in the lower liquid slug velocity and in the sodium velocity in the pipe between the pump outlet and 
the lower plenum due to design (loop-type vs. pool-type) are due to the difference in inertial head in the inlet pipe and are larger than the effects of sodium compressibility and structural material elasticity. The latter are not negligible in the case of the loop design, but are probably not large enough to make an important difference in the course of an accident. For the loop case during the $300 \mathrm{msec}$ of the pressure transient, the lower slug velocity changes from $3.4 \mathrm{ft} / \mathrm{sec}$ to $-3.1 \mathrm{ft} / \mathrm{sec}$ (the minus sign indicates reversal of flow direction from the normal) in the compressible and elastic case vs. from $3.4 \mathrm{ft} / \mathrm{sec}$ to $-1.5 \mathrm{ft} / \mathrm{sec}$ in the incompressible and rigid case. This difference is larger for a loop design with a $900 \mathrm{ft}$ long pipe between the pump outlet and the lower plenum. At the end of the transient the sodium velocity has a variation of a factor of 2 over the length of the pipe between pump outlet and lower plenum in the compressible and elastic case vs. no variation in the incompressible and rigid case. In the case of the pool design the sodium compressibility and material elasticity effects are insignificant (the lower slug velocity changes from $3.4 \mathrm{ft} / \mathrm{sec}$ to about $-14.3 \mathrm{ft} / \mathrm{sec}$, and the sodium velocity in the $50 \mathrm{ft}$-pipe changes to about $-11.5 \mathrm{ft} / \mathrm{sec}$ ). The maximum pressures in the lower plenum during the transient are about 183 psi and 137 psi for the loop and pool designs and undergo relatively small changes when sodium compressibility and structural material elasticity are taken into account. However, in the case of the loop design the pressure difference between the inlet plenum and the core, which is small, is considerably larger if compressibility and elasticity are taken into account. The sodium velocity in the bypass channel (non-boiling) rises from $1.9 \mathrm{ft} / \mathrm{sec}$ to 6.5 $\mathrm{ft} / \mathrm{sec}$ for the loop design and to $5.4 \mathrm{ft} / \mathrm{sec}$ for the pool design, and is not sensitive to compressibility and elasticity assumption for either design. For both designs, irrespective of the assumptions about compressibility and elasticity, the upper liquid slug velocity in the core channel rises from 3.4 $\mathrm{ft} / \mathrm{sec}$ to $34.5 \mathrm{ft} / \mathrm{sec}$ and the pressure at pump outlet remains practically constant.

Although the sodium compressibility and structural material elasticity effects found in the present calculations are not large enough to require taking into account, it seems desirable to carry out PTA-2 calculations in which the core is modeled by two or more channels with different bubble pressure-time curves. These effects on the lower slug velocity may be larger with such a model than with the 1 -core channel model. The same number of core channels may be used in a SAS calculation and the results of both codes may be compared. Sometimes in SAS calculations a fictitiously high value of the lower plenum volume (several times the actual volume) is used to account for its elastic strain in the computation of sodium pressure in the lower plenum. This assumption also may be verified. 
REFERENCES

1. C. K. Youngdahl and C. A. Kot, PTA-1, A Computer Program for Analysis of Pressure Transients in Hydraulic Networks, Including the Effects of Pipe Plasticity, ANL-76-64, Argonne National Laboratory, Argonne (November 1976).

2. Y. W. Shin and W. L. Chen, Numerical Fluid-Hammer Analysis by the Method of Characteristics in Complex Piping Networks, Nucl. Eng. Des. 33, pp. 357-369 (1975).

3. H. H. Hummel, P. A. Pizzica and Kalimullah, Studies of Unprotected Lossof-Flow Accidents for the Clinch River Breeder Reactor, ANL-76-51, Argonne National Laboratory, Argonne (April 1976). 
TABLE I. Typical Features of the Primary Heat Transport System of Various Loop-Type LMFBR Designs

\begin{tabular}{|c|c|}
\hline Electric power & $350-1200 \mathrm{MWe}$ \\
\hline Pump position & Commonly hot leg \\
\hline Pipe diameter & $24-40$ Inch \\
\hline Sodium velocity & $\leqslant 30 \mathrm{ft} / \mathrm{sec}$ \\
\hline Number of loops & 3 or 4 \\
\hline IHX pressure drop & $15-25$ psi \\
\hline Check valve pressure drop & 5-10 psi \\
\hline $\begin{array}{l}\text { Length of pipe between pump } \\
\text { outlet and inlet nozzle }\end{array}$ & $400-650 \mathrm{ft}$ \\
\hline $\begin{array}{l}\text { Pressure drop in the pipe } \\
\text { pump outlet and inlet noz } \\
\text { (including minor losses) }\end{array}$ & $20-30 \mathrm{psi}$ \\
\hline Subassembly pressure drop & $\sim 100 \mathrm{psi}$ \\
\hline $\begin{array}{l}\text { Pressure Drop } \\
\text { (vessel inlet nozzle to } \\
\text { (subassembly outlet to }\end{array}$ & $\begin{array}{l}\text { (t) }+ \\
\text { 2ozzle) }\end{array}$ \\
\hline Pump head & $150-180$ psi \\
\hline $\begin{array}{l}\text { Flow during pump coastdown } \\
\text { without pony motor }\end{array}$ & $\begin{array}{l}18-22 \% \text { of normal flow at } 20 \mathrm{sec} \text {. } \\
10-14 \% \text { of normal flow at } 30 \mathrm{sec} \text {. }\end{array}$ \\
\hline
\end{tabular}


TABLE II. Physical Dimensions and Initial Conditions of the 1-D Model of the Primary System of a CRBR-sized LMFBR Used in the Pressure Transient Analysis

\begin{tabular}{|c|c|c|c|c|c|c|c|c|}
\hline Serial No. & $\begin{array}{l}\text { Pipe ident., } \\
\text { first jn./ } \\
\text { second jn. }\end{array}$ & $\begin{array}{c}\text { Length } \\
\mathrm{ft}\end{array}$ & $\begin{array}{l}\text { Inclination } \\
\text { to horizona., } \\
\text { deg }\end{array}$ & $\begin{array}{l}\text { Hyd. dia./ } \\
\text { wall thick., } \\
\text { in }\end{array}$ & $\begin{array}{l}\text { Surface } \\
\text { roughness, } \\
\text { in }\end{array}$ & $\begin{array}{l}\text { Flow } \\
\text { area, } \\
\text { in }^{2}\end{array}$ & $\begin{array}{c}\text { Initialb } \\
\text { pressure } \\
\text { first jn./ } \\
\text { second jn., } \\
\text { psi }\end{array}$ & $\begin{array}{l}\text { Initial } \\
\text { velocity } \\
\mathrm{ft} / \mathrm{sec}\end{array}$ \\
\hline 1 & $8 / 2$ & 5.3 & -90.0 & $0.157 / 0.0017$ & 0.0044 & 1331.4 & $40.10 / 31.94$ & 3.40 \\
\hline 2 & $3 / 8$ & 7.7 & -90.0 & $2.9 / 0.12$ & 0.0 & 1331.4 & $42.98 / 40.10$ & 3.40 \\
\hline 3 & $3 / 1$ & 29.0 & -90.0 & $0.157 / 0.0017$ & 0.0597 & 806.0 & $42.98 / 21.30$ & 1.88 \\
\hline 4 & $4 / 3$ & 9.0 & -90.0 & $243.0 / 4.5$ & 0.0 & 46377.0 & $46.35 / 42.98$ & 0.13 \\
\hline 5 & $2 / 7$ & 4.0 & -90.0 & $0.157 / 0.0017$ & 0.0044 & 1331.4 & $31.94 / 25.79$ & 3.40 \\
\hline 6 & $7 / 1$ & 12.0 & -90.0 & $2.9 / 0.12$ & 0.0 & 1331.4 & $25.79 / 21.30$ & 3.40 \\
\hline 7 & $1 / 5$ & 10.6 & 90.0 & $243.0 / 4.5$ & 0.0 & 46377.0 & $21.30 / 25.27$ & 0.13 \\
\hline 8 & $1 / 6$ & 10.1 & -90.0 & $243.0 / 4.5$ & 0.0 & 46377.0 & $21.30 / 17.52$ & 0.0 \\
\hline 9 & $5 / 11$ & 100.0 & -1.55 & $35.0 / 0.5$ & 4.095 & 2886.3 & $25.27 / 21.26$ & 2.10 \\
\hline 10 & $11 / 10$ & 5.0 & 90.0 & $100.0 / 1.75$ & 0.0 & 23562.0 & $21.26 / 23.13$ & 0.26 \\
\hline 11 & $11 / 12$ & 10.0 & -90.0 & $100.0 / 1.75$ & 0.0 & 23562.0 & $21.26 / 17.52$ & 0.0 \\
\hline 12 & $10 / 9$ & 5.0 & 90.0 & $100.0 / 1.75$ & 0.0 & 23562.0 & d & 0.26 \\
\hline 13 & $9 / 4$ & c & $c$ & $23.0 / 0.5$ & c & 1246.4 & $d / 46.35$ & 4.85 \\
\hline
\end{tabular}

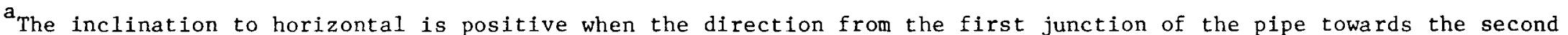
junction points down.

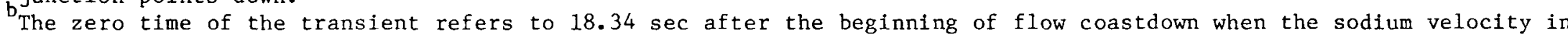
pipe 13 (from junction 9 to 4 ) has decreased to $21.1 \%$ of the steady state value of $23.0 \mathrm{ft} / \mathrm{sec}$.

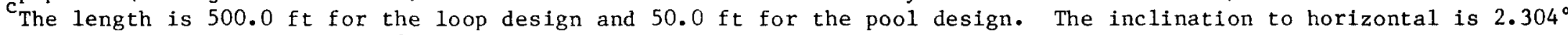
for the loop design and $23.7^{\circ}$ for the pool design. The surface roughness is 0.1258 in for the loop design and 5.967 in for the pool design.

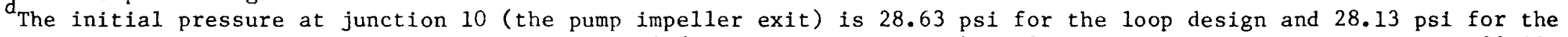
pool design. The initial pressure at junction 9 (the pump vessel exit) is 30.50 psi for the loop design and 30.00 psi for the pool design. 


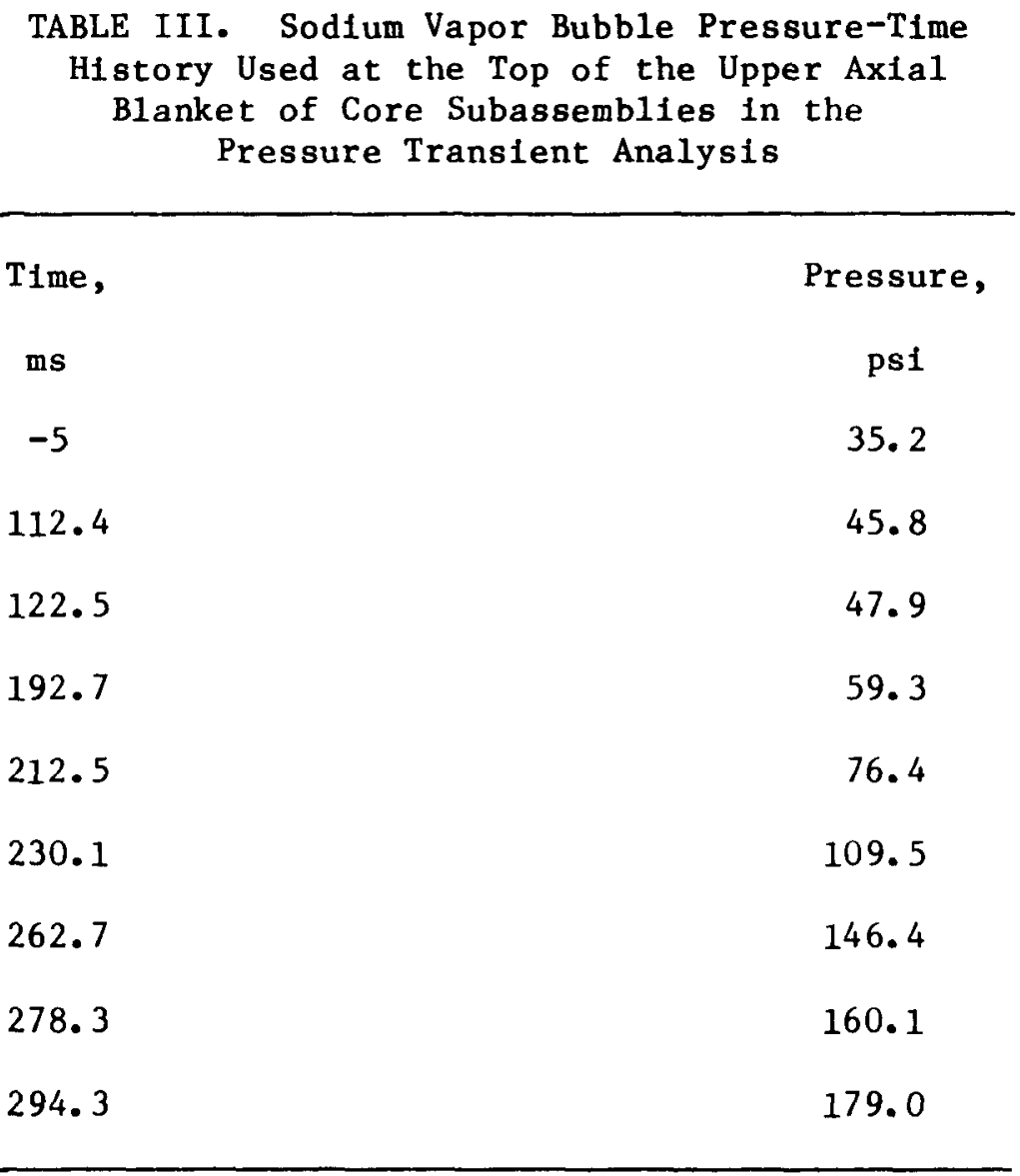


TABLE IV. Results of Pressure Transient Analysis for the Loop Design,

Elastic and Compressible Case ${ }^{a}$

\begin{tabular}{|c|c|c|c|c|c|c|c|c|c|c|c|}
\hline $\begin{array}{l}\text { Time, } \\
\text { ms }\end{array}$ & $\begin{array}{l}\mathrm{P}_{2} \\
\text { psi }\end{array}$ & $\begin{array}{l}\mathrm{P}_{3} \\
\text { psi }\end{array}$ & $\begin{array}{l}\mathrm{P}_{\mathrm{a}} \\
\mathrm{psi}\end{array}$ & $P_{9} \underset{p s i}{(p i p e)}$ & $\begin{array}{c}\mathrm{U}_{2} \begin{array}{c}\text { (lower) } \\
\mathrm{ft} / \mathrm{sec}\end{array} \\
\text { (lowe }\end{array}$ & $\begin{array}{c}\mathrm{U}_{2} \text { (upper) } \\
\mathrm{ft} / \mathrm{sec}\end{array}$ & $\mathrm{U}_{3}$ & $\begin{array}{l}\text { (by pass) } \\
\mathrm{ft} / \mathrm{sec}\end{array}$ & $\begin{array}{c}\mathrm{U}_{4} \\
\mathrm{ft} / \mathrm{sec}\end{array}$ & $\begin{array}{c}\mathrm{U}_{\mathrm{a}} \\
\mathrm{ft} / \mathrm{sec}\end{array}$ & $\begin{array}{c}\mathrm{U}_{9} \\
\mathrm{ft} / \mathrm{sec}\end{array}$ \\
\hline 0 & 31.94 & 42.98 & 38.42 & 30.50 & 3.40 & 3.40 & & 1.88 & 4.85 & 4.85 & 4.85 \\
\hline 16 & 37.10 & 42.75 & 38.43 & 30.32 & 3.38 & 4.01 & & 1.83 & 4.83 & 4.83 & 4.82 \\
\hline 32 & 38.54 & 43.51 & 38.42 & 30.40 & 3.27 & 4.75 & & 1.83 & 4.79 & 4.80 & 4.80 \\
\hline 48 & 39.99 & 45.40 & 38.40 & 30.52 & 3.15 & 5.54 & & 1.87 & 4.73 & 4.78 & 4.78 \\
\hline 64 & 41.43 & 47.20 & 38.03 & 30.44 & 3.08 & 6.35 & & 1.96 & 4.68 & 4.75 & 4.75 \\
\hline 80 & 42.87 & 48.28 & 38.77 & 30.31 & 3.02 & 7.20 & & 2.06 & 4.63 & 4.71 & 4.72 \\
\hline 96 & 44.32 & 49.18 & 40.68 & 30.26 & 2.92 & 8.07 & & 2.15 & 4.59 & 4.66 & 4.69 \\
\hline 112 & 45.76 & 50.50 & 42.42 & 30.35 & 2.79 & 8.93 & & 2.23 & 4.54 & 4.60 & 4.68 \\
\hline 128 & 48.79 & 52.53 & 43.46 & 30.40 & 2.60 & 9.84 & & 2.33 & 4.48 & 4.55 & 4.63 \\
\hline 144 & 51.39 & 55.56 & 44.39 & 30.43 & 2.40 & 10.83 & & 2.46 & 4.41 & 4.51 & 4.54 \\
\hline 160 & 53.99 & 58.55 & 46.13 & 30.37 & 2.27 & 11.85 & & 2.63 & 4.33 & 4.47 & 4.46 \\
\hline 176 & 56.59 & 60.89 & 47.51 & 30.37 & 2.16 & 12.87 & & 2.78 & 4.26 & 4.40 & 4.39 \\
\hline 192 & 59.18 & 63.03 & 48.74 & 30.39 & 2.00 & 13.89 & & 2.92 & 4. 21 & 4.30 & 4.34 \\
\hline 208 & 72.50 & 67.64 & 49.83 & 30.43 & 1.34 & 15.29 & & 3.08 & 4.11 & 4.19 & 4.27 \\
\hline 224 & 97.98 & 82.72 & 50.98 & 30.46 & -0.23 & 17.72 & & 3.48 & 3.82 & 4.10 & 4.18 \\
\hline 240 & 120.68 & 113.64 & 52.23 & 30.50 & -2.16 & 21.42 & & 4.33 & 3.21 & 4.03 & 4.05 \\
\hline 256 & 138.78 & 144.44 & 54.98 & 30.46 & -2.56 & 25.31 & & 5.35 & 2.61 & 3.91 & 3.93 \\
\hline 272 & 154.54 & 160.91 & 67.94 & 30.44 & -2.27 & 29.01 & & 6.01 & 2.27 & 3.61 & 3.82 \\
\hline 288 & 171.52 & 168.35 & 97.15 & 30.45 & -2.46 & 32.28 & & 6.32 & 2.09 & 3.00 & 3.73 \\
\hline 296 & 179.00 & 173.20 & 113.45 & 30.59 & -2.90 & 33.79 & & 6.44 & 1.98 & 2.66 & 3.67 \\
\hline 300 & 179.00 & 176.44 & 120.83 & 30.53 & -3.12 & 34.49 & & 6.51 & 1.91 & 2.50 & 3.63 \\
\hline
\end{tabular}

asymbol ' $P$ ' stands for pressure and ' $U$ ' for velocity. The subscripts are the junction numbers. The subscript 'a' refers to the midpoint of the $500 \mathrm{ft}$ long pipe between functions 9 and 4 . 
TABLE V. Results of Pressure Transient Analysis for the Loop Design, Rigid and Compressible Case

\begin{tabular}{|c|c|c|c|c|c|c|c|c|c|c|c|}
\hline $\begin{array}{l}\text { Time, } \\
\text { ms }\end{array}$ & $\begin{array}{l}\mathrm{P}_{2} \\
\mathrm{psi}\end{array}$ & $\begin{array}{l}\mathrm{P}_{3} \\
\mathrm{psi}\end{array}$ & $\begin{array}{l}P_{a} \\
\text { psi }\end{array}$ & $P_{9} \begin{array}{l}\text { (pipe) } \\
\text { psi }\end{array}$ & $\begin{array}{c}\mathrm{U}_{2} \text { (lower) } \\
\mathrm{ft} / \mathrm{sec}\end{array}$ & $\begin{array}{c}\mathrm{U}_{2} \text { (upper) } \\
\mathrm{ft} / \mathrm{sec}\end{array}$ & $\mathrm{U}_{3}$ & $\begin{array}{l}\text { (by pass) } \\
\mathrm{ft} / \mathrm{sec}\end{array}$ & $\begin{array}{c}U_{4} \\
\mathrm{ft} / \mathrm{sec}\end{array}$ & $\begin{array}{c}\mathrm{U}_{\mathrm{a}} \\
\mathrm{ft} / \mathrm{sec}\end{array}$ & $\begin{array}{c}\text { Ug } \\
\mathrm{ft} / \mathrm{sec}\end{array}$ \\
\hline 0 & 31.94 & 42.98 & 38.42 & 30.50 & 3.40 & 3.40 & & 1.88 & 4.85 & 4.85 & 4.85 \\
\hline 16 & 37.10 & 42.67 & 38.42 & 30.37 & 3.39 & 4.00 & & 1.84 & 4.83 & 4.83 & 4.83 \\
\hline 32 & 38.54 & 44.40 & 38.34 & 30.28 & 3.30 & 4.73 & & 1.84 & 4.79 & 4.80 & 4.80 \\
\hline 48 & 39.99 & 45.90 & 37.98 & 30.44 & 3.27 & 5.51 & & 1.90 & 4.74 & 4.78 & 4.77 \\
\hline 64 & 41.43 & 46.64 & 39.61 & 30.37 & 3.18 & 6.35 & & 1.97 & 4.71 & 4.73 & 4.75 \\
\hline 80 & 42.87 & 48.21 & 41.25 & 30.43 & 3.07 & 7.21 & & 2.05 & 4.66 & 4.69 & 4.73 \\
\hline 96 & 44.32 & 49.68 & 42.01 & 30.39 & 2.99 & 8.08 & & 2.15 & 4.62 & 4.65 & 4.66 \\
\hline 112 & 45.76 & 50.80 & 44.01 & 30.45 & 2.89 & 8.94 & & 2.24 & 4.58 & 4.61 & 4.61 \\
\hline 128 & 48.79 & 53.08 & 43.79 & 30.38 & 2.73 & 9.85 & & 2.34 & 4.53 & 4.55 & 4.56 \\
\hline 144 & 51.39 & 56.42 & 43.36 & 30.43 & 2.61 & 10.83 & & 2.49 & 4.48 & 4.50 & 4.50 \\
\hline 160 & 53.99 & 57.95 & 44.81 & 30.43 & 2.48 & 11.84 & & 2.64 & 4.39 & 4.44 & 4.44 \\
\hline 176 & 56.59 & 60.28 & 46.21 & 30.42 & 2.26 & 12.87 & & 2.76 & 4.31 & 4.36 & $4.3 y$ \\
\hline 192 & 59.18 & 63.74 & 47.94 & 30.49 & 2.12 & 13.88 & & 2.91 & 4.23 & 4.28 & 4.32 \\
\hline 208 & 72.50 & 70.04 & 50.67 & 30.41 & 1.57 & 15.28 & & 3.10 & 4.10 & 4.20 & 4.22 \\
\hline 224 & 97.98 & 90.72 & 52.75 & 30.52 & 0.55 & 17.70 & & 3.61 & 3.81 & 4.11 & 4.13 \\
\hline 240 & 120.68 & 123.10 & 57.51 & 30.45 & -0.36 & 21.42 & & 4.56 & 3.41 & 3.96 & 4.02 \\
\hline 256 & 138.78 & 139.06 & 76.52 & 30.56 & -0.55 & 25.31 & & 5.37 & 3.16 & 3.66 & 3.90 \\
\hline 272 & 154.54 & 152.35 & 106.20 & 30.65 & -1.31 & 29.01 & & 5.80 & 2.92 & 3.22 & 3.70 \\
\hline 288 & 171.52 & 171.14 & 120.15 & 31.03 & -1.85 & 32.27 & & 6.26 & 2.62 & 2.95 & 3.20 \\
\hline 296 & 179.00 & 179.92 & 124.55 & 31.14 & -2.09 & 33.81 & & 6.48 & 2.47 & 2.84 & 3.82 \\
\hline 300 & 179.00 & 183.83 & 126.83 & 31.11 & -2.13 & 34.45 & & 6.58 & 2.40 & 2.70 & 3.61 \\
\hline
\end{tabular}


TABLE VI. Results of Pressure Transient Analysis for the Loop Design, Rig1d and Incompressible Case

\begin{tabular}{|c|c|c|c|c|c|c|c|c|c|c|}
\hline $\begin{array}{l}\text { Time, } \\
\text { ms }\end{array}$ & $\begin{array}{l}\mathrm{P}_{2} \\
\mathrm{psi}\end{array}$ & $\begin{array}{l}\mathrm{P}_{3} \\
\mathrm{psi}\end{array}$ & $\begin{array}{l}\mathrm{Pa}_{\mathrm{a}} \\
\mathrm{psi}\end{array}$ & $P_{9}(p i p e)$ & $\begin{array}{l}\mathrm{U}_{2} \text { (lower) } \\
\mathrm{ft} / \mathrm{sec}\end{array}$ & $\mathrm{U}_{2}$ (upper) & $\begin{array}{c}\mathrm{U}_{3} \text { (by pass) } \\
\mathrm{ft} / \mathrm{sec}\end{array}$ & $\begin{array}{c}\mathrm{U}_{4} \\
\mathrm{ft} / \mathrm{sec}\end{array}$ & $\begin{array}{c}\mathrm{U}_{\mathrm{a}} \\
\mathrm{ft} / \mathrm{sec}\end{array}$ & $\begin{array}{c}\mathrm{U}_{9} \\
\mathrm{ft} / \mathrm{sec}\end{array}$ \\
\hline 0 & 31.94 & 42.98 & 38.42 & 30.50 & 3.40 & 3.40 & 1.88 & 4.85 & 4.85 & 4.85 \\
\hline 16 & 37.10 & 43.70 & 37.98 & 30.36 & 3.40 & 4.05 & 1.84 & 4.83 & 4.83 & 4.83 \\
\hline 32 & 38.54 & 44.68 & 39.71 & 30.36 & 3.37 & 4.76 & 1.86 & 4.80 & 4.80 & 4.80 \\
\hline 48 & 39.99 & 45.69 & 39.46 & 30.37 & 3.31 & 5.54 & 1.91 & 4.76 & 4.76 & 4.76 \\
\hline 64 & 41.43 & 46.96 & 40.87 & 30.38 & 3.23 & 6.35 & 1.98 & 4.73 & 4.73 & 4.73 \\
\hline 80 & 42.87 & 48.24 & 40.74 & 30.38 & 3.14 & 7.20 & 2.06 & 4.69 & 4.69 & 4.69 \\
\hline 96 & 44.32 & 49.64 & 41.86 & 30.39 & 3.05 & 8.06 & 2.15 & 4.65 & 4.65 & 4.65 \\
\hline 112 & 45.76 & 50.96 & 42.07 & 30.40 & 2.95 & 8.92 & 2.24 & 4.60 & 4.60 & 4.60 \\
\hline 128 & 48.79 & 53.63 & 43.66 & 30.41 & 2.83 & 9.83 & 2.36 & 4.55 & 4.55 & 4.55 \\
\hline 144 & 51.39 & 55.96 & 44.79 & 30.42 & 2.69 & 10.82 & 2.49 & 4.49 & 4.49 & 4.49 \\
\hline 160 & 53.99 & 58.36 & 46.03 & 30.43 & 2.54 & 11.83 & 2.64 & 4.42 & 4.42 & 4.42 \\
\hline 176 & 56.59 & 60.83 & 47.41 & 30.44 & 2.39 & 12.86 & 2.78 & 4.35 & 4.35 & 4.35 \\
\hline 192 & 59.18 & 63.30 & 48.38 & 30.45 & 2.24 & 13.88 & 2.91 & 4.27 & 4.27 & 4.27 \\
\hline 208 & 72.50 & 74.81 & 54.23 & 30.48 & 1.97 & 15.26 & 3.19 & 4.17 & 4.17 & 4.18 \\
\hline 224 & 97.98 & 97.05 & 64.87 & 30.54 & 1.49 & 17.67 & 3.78 & 4.03 & 4.04 & 4.04 \\
\hline 240 & 120.68 & 118.99 & 77.55 & 30.61 & 0.79 & 21.38 & 4.61 & 3.82 & 3.83 & 3.83 \\
\hline 256 & 138.78 & 137.28 & 85.22 & 30.65 & 0.14 & 25.27 & 5.28 & 3.57 & 3.57 & 3.57 \\
\hline 272 & 154.54 & 153.69 & 95.13 & 30.72 & -0.47 & 29.97 & 5.81 & 3.26 & 3.26 & 3.26 \\
\hline 288 & 171.52 & 170.17 & 100.98 & 30.76 & -1.06 & 32.23 & 6.24 & 2.91 & 2.91 & 2.91 \\
\hline 296 & 179.00 & 178.49 & 108.69 & 30.79 & $-1 \cdot 36$ & 33.78 & 6.45 & 2.71 & 2.71 & 2.71 \\
\hline 300 & 179.00 & 178.43 & 103.61 & 30.78 & -1.50 & 34.46 & 6.53 & 2.62 & 2.62 & 2.61 \\
\hline
\end{tabular}


TABLE VII. Results of Pressure Transient Analysis for the Pool Design, Elastic and Compressible Case

\begin{tabular}{|c|c|c|c|c|c|c|c|c|c|}
\hline $\begin{array}{l}\text { Time, } \\
\text { ms }\end{array}$ & $\begin{array}{l}P_{2} \\
\text { psi }\end{array}$ & $\begin{array}{l}\mathrm{P}_{3} \\
\mathrm{psi}\end{array}$ & $\begin{array}{l}P_{4} \\
\text { psi }\end{array}$ & $\mathrm{P}_{9}(p i p e)$ & $\begin{array}{c}\mathrm{u}_{2} \text { (lower) } \\
\mathrm{ft} / \mathrm{sec}\end{array}$ & $\begin{array}{c}\mathrm{U}_{2} \text { (upper) } \\
\mathrm{ft} / \mathrm{sec}\end{array}$ & $\begin{array}{c}U_{3} \text { (by pass) } \\
\mathrm{ft} / \mathrm{sec}\end{array}$ & $\begin{array}{c}\mathrm{U}_{4} \\
\mathrm{ft} / \mathrm{sec}\end{array}$ & $\begin{array}{c}U_{9} \\
\mathrm{ft} / \mathrm{sec}\end{array}$ \\
\hline 0 & 31.94 & 42.98 & 46.35 & 30.00 & 3.40 & 3.40 & 1.88 & 4.85 & 4.85 \\
\hline 16 & 37.10 & 41.55 & 44.93 & 29.89 & 3.34 & 4.01 & 1.81 & 4.62 & 4.60 \\
\hline 32 & 38.54 & 40.70 & 44.01 & 30.03 & 3.01 & 4.75 & 1.74 & 4.41 & 4.41 \\
\hline 48 & 39.99 & 42.98 & 46.28 & 30.20 & 2.63 & 5.54 & 1.73 & 4.18 & 4.21 \\
\hline 64 & 41.43 & 45.73 & 49.06 & 30.17 & 2.42 & 6.35 & 1.81 & 3.89 & 3.91 \\
\hline 80 & 42.87 & 46.00 & 49.32 & 30.03 & 2.24 & 7.20 & 1.91 & 3.57 & 3.56 \\
\hline 96 & 44.32 & 45.23 & 48.51 & 29.96 & 1.86 & 8.07 & 1.95 & 3.26 & 3.25 \\
\hline 112 & 45.76 & 46.38 & 49.66 & 30.18 & 1.37 & 8.93 & 1.98 & 2.93 & 2.94 \\
\hline 128 & 48.79 & 49.39 & 52.68 & 30.33 & 0.89 & 9.85 & 2.08 & 2.55 & 2.57 \\
\hline 144 & 51.39 & 52.32 & 55.61 & 30.38 & 0.46 & 10.84 & 2.24 & 2.10 & 2.11 \\
\hline 160 & 53.99 & 53.70 & 56.99 & 30.36 & -0.01 & 11.85 & 2.38 & 1.60 & 1.59 \\
\hline 176 & 56.59 & 54.82 & 58.09 & 30.42 & -0.64 & 12.88 & 2.49 & 1.06 & 1.06 \\
\hline 192 & 59.18 & 57.21 & 60.48 & 30.49 & -1.35 & 13.89 & 2.60 & 0.47 & 0.46 \\
\hline 208 & 72.50 & 62.11 & 65.28 & 30.54 & -2.50 & 15.29 & 2.77 & -0.23 & -0.18 \\
\hline 224 & 97.98 & 75.86 & 78.93 & 30.76 & -4.52 & 17.72 & 3.17 & -1.17 & -1.06 \\
\hline 240 & 120.68 & 102.20 & 105.27 & 31.40 & -6.92 & 21.42 & 3.95 & -2.65 & -2.50 \\
\hline 256 & 138.78 & 123.48 & 126.41 & 31.86 & -8.24 & 25.32 & 4.80 & -4.72 & -4.66 \\
\hline 272 & 154.54 & 127.70 & 130.25 & 31.94 & -9.76 & 29.01 & 5.23 & -7.13 & -7.14 \\
\hline 288 & 171.52 & 126.55 & 128.64 & 31.83 & -12.33 & 32.28 & 5.32 & -9.55 & -9.55 \\
\hline 296 & 179.00 & 129.05 & 130.95 & 31.82 & -13.89 & 33.80 & 5.36 & -10.77 & -10.74 \\
\hline 300 & 179.00 & 131.26 & 133.07 & 31.79 & -14.60 & 34.49 & 5.40 & -11.39 & $-11 \cdot 35$ \\
\hline
\end{tabular}


TABLE VIII. Results of Pressure Transient Analysis for the Pool Design, Rigid and Compressible Case

\begin{tabular}{|c|c|c|c|c|c|c|c|c|c|}
\hline $\begin{array}{c}\text { Time, } \\
\text { ms }\end{array}$ & $\begin{array}{l}\mathrm{p}^{2} \\
\mathrm{psi}\end{array}$ & $\begin{array}{l}\mathrm{P}^{3} \\
\mathrm{psi}\end{array}$ & $\begin{array}{l}\mathrm{P}^{4} \\
\mathrm{psi}\end{array}$ & $\begin{array}{c}\mathrm{P}^{9} \text { (pipe) } \\
\text { psi }\end{array}$ & $\begin{array}{c}\mathrm{U}^{2} \text { (lower) } \\
\mathrm{ft} / \mathrm{sec}\end{array}$ & $\begin{array}{l}\mathrm{U}^{2} \text { (upper) } \\
\mathrm{ft} / \mathrm{sec}\end{array}$ & $\begin{array}{c}\text { U3 (by pass) } \\
\mathrm{ft} / \mathrm{sec}\end{array}$ & $\begin{array}{c}\mathrm{U} 4 \\
\mathrm{ft} / \mathrm{sec}\end{array}$ & $\begin{array}{c}\mathrm{Ug} \\
\mathrm{ft} / \mathrm{sec}\end{array}$ \\
\hline 0 & 31.94 & 42.98 & 46.35 & 30.00 & 3.40 & 3.40 & 1.88 & 4.85 & 4.85 \\
\hline 16 & 37.10 & 40.40 & 43.70 & 30.05 & 3.30 & 4.00 & 1.80 & 4.62 & 4.63 \\
\hline 32 & 38.54 & 42.50 & 45.83 & 29.98 & 2.96 & 4.73 & 1.73 & 4.42 & 4.43 \\
\hline 48 & 39.99 & 44.56 & 47.88 & 30.23 & 2.83 & 5.51 & 1.80 & 4.15 & 4.14 \\
\hline 64 & 41.43 & 42.98 & 46.27 & 30.11 & 2.51 & 6.35 & 1.82 & 3.87 & 3.88 \\
\hline 80 & 42.87 & 46.03 & 49.34 & 30.21 & 2.14 & 7.21 & 1.86 & 3.59 & 3.59 \\
\hline 96 & 44.32 & 46.60 & 49.92 & 30.19 & 1.90 & 8.08 & 1.96 & 3.25 & 3.24 \\
\hline 112 & 45.76 & 46.34 & 49.63 & 30.32 & 1.45 & 8.94 & 2.00 & 2.91 & 2.92 \\
\hline 128 & 48.79 & 50.11 & 53.41 & 30.25 & 0.99 & 9.85 & 2.10 & 2.53 & 2.54 \\
\hline 144 & 51.39 & 51.60 & 54.88 & 30.46 & 0.59 & 10.83 & 2.25 & 2.07 & 2.07 \\
\hline 160 & 53.99 & 52.67 & 55.94 & 30.37 & -0.02 & 11.84 & 2.35 & 1.59 & 1.60 \\
\hline 176 & 56.59 & 56.43 & 59.71 & 30.52 & -0.61 & 12.87 & 2.49 & 1.04 & 1.05 \\
\hline 192 & 59.18 & 57.33 & 60.58 & 30.46 & -1.20 & 13.88 & 2.63 & 0.43 & 0.43 \\
\hline 208 & 72.50 & 63.65 & 66.83 & 30.63 & -2.36 & 15.28 & 2.78 & -0.26 & -0.23 \\
\hline 224 & 97.98 & 83.17 & 86.28 & 31.03 & -3.89 & 17.70 & 3.29 & -1.31 & -1.25 \\
\hline 240 & 120.68 & 106.08 & 109.11 & 31.59 & -5.70 & 21.42 & 4.12 & -2.93 & -2.89 \\
\hline 256 & 138.78 & 113.33 & 116.10 & 31.60 & -7.59 & 25.32 & 4.70 & -4.95 & -4.94 \\
\hline 272 & 154.54 & 123.10 & 125.63 & 31.81 & -10.14 & 29.01 & 5.02 & -7.15 & -7.13 \\
\hline 288 & 171.52 & 132.99 & 135.15 & 31.88 & -12.39 & 32.28 & 5.35 & -9.61 & -9.60 \\
\hline 296 & 179.00 & 135.38 & 137.29 & 32.00 & -13.65 & 33.81 & 5.47 & -10.90 & -10.90 \\
\hline 300 & 179.00 & 136.37 & 138.21 & 31.90 & -14.22 & 34.49 & 5.51 & -11.55 & -11.54 \\
\hline
\end{tabular}


TABLE IX. Results of Pressure Transient Analysis for the Pool Design, Rigid and Incompressible Case

\begin{tabular}{|c|c|c|c|c|c|c|c|c|c|c|}
\hline $\begin{array}{l}\text { Time, } \\
\text { ms }\end{array}$ & $\begin{array}{l}\mathrm{P}_{2} \\
\text { psi }\end{array}$ & $\begin{array}{l}\mathrm{P}_{3} \\
\text { psi }\end{array}$ & $\begin{array}{l}\mathrm{P}_{4} \\
\text { psi }\end{array}$ & $\begin{array}{c}\mathrm{P}_{9}(p i p e) \\
\text { psi }\end{array}$ & $\begin{array}{c}\mathrm{U}_{2} \text { (l lower) } \\
\mathrm{ft} / \mathrm{sec}\end{array}$ & $\begin{array}{c}\mathrm{U}_{2} \text { (upper) } \\
\mathrm{ft} / \mathrm{sec}\end{array}$ & $\mathrm{U}_{3}$ & $\begin{array}{l}\text { (by pass) } \\
\mathrm{ft} / \mathrm{sec}\end{array}$ & $\begin{array}{c}\mathrm{U}_{4} \\
\mathrm{ft} / \mathrm{sec}\end{array}$ & $\begin{array}{c}\mathrm{U}_{9} \\
\mathrm{ft} / \mathrm{sec}\end{array}$ \\
\hline 0 & 31.94 & 42.98 & 46.35 & 30.00 & 3.40 & 3.40 & & 1.88 & 4.85 & 4.85 \\
\hline 16 & 37.10 & 40.68 & 43.97 & 30.01 & 3.26 & 4.05 & & 1.79 & 4.64 & 4.64 \\
\hline 32 & 38.54 & 43.06 & 46.37 & 30.08 & 2.06 & 4.76 & & 1.76 & 4.40 & 4.40 \\
\hline 48 & 39.99 & 43.38 & 46.68 & 30.10 & 2.80 & 5.54 & & 1.78 & 4.15 & 4.15 \\
\hline 64 & 41.43 & 44.26 & 47.55 & 30.13 & 2.52 & 6.35 & & 1.82 & 3.87 & 3.87 \\
\hline 80 & 42.87 & 45.50 & 48.81 & 30.18 & 2.21 & 7.20 & & 1.88 & 3.57 & 3.57 \\
\hline 96 & 44.32 & 46.18 & 49.49 & 30.20 & 1.86 & 8.06 & & 1.94 & 3.25 & 3.25 \\
\hline 112 & 45.76 & 47.43 & 50.74 & 30.25 & 1.49 & 8.92 & & 2.01 & 2.90 & 2.90 \\
\hline 128 & 48.79 & 49.44 & 52.73 & 30.31 & 1.07 & 9.83 & & 2.11 & 2.51 & 2.51 \\
\hline 144 & 51.39 & 51.43 & 54.72 & 30.36 & 0.58 & 10.82 & & 2.23 & 2.06 & 2.06 \\
\hline 160 & 53.99 & 53.53 & 56.81 & 30.42 & 0.04 & 11.83 & & 2.36 & 1.57 & 1.57 \\
\hline 176 & 56.59 & 55.56 & 58.83 & 30.47 & -0.55 & 12.86 & & 2.49 & 1.02 & 1.02 \\
\hline 192 & 59.18 & 57.56 & 60.82 & 30.52 & -1.19 & 13.87 & & 2.61 & 0.42 & 0.42 \\
\hline 208 & 72.50 & 66.87 & 70.08 & 30.71 & -2.04 & 15.26 & & 2.86 & -0.33 & -0.33 \\
\hline 224 & 97.98 & 84.93 & 88.04 & 31.08 & -3.37 & 17.67 & & 3.37 & -1.42 & -1.42 \\
\hline 240 & 120.68 & 101.92 & 104.89 & 31.42 & -5.32 & 21.38 & & 4.09 & -3.03 & -3.03 \\
\hline 256 & 138.78 & 114.42 & 117.21 & 31.66 & -7.50 & 25.27 & & 4.65 & -5.00 & -5.00 \\
\hline 272 & 154.54 & 123.63 & 126.14 & 31.81 & -9.85 & 28.97 & & 5.05 & -7.25 & -7.25 \\
\hline 288 & 171.52 & 132.14 & 134.27 & 31.93 & -12.29 & 32.23 & & 5.32 & -9.69 & -9.69 \\
\hline 296 & 179.00 & 135.06 & 136.95 & 31.96 & -13.57 & 33.78 & & 5.45 & -10.97 & -10.97 \\
\hline 300 & 179.00 & 133.47 & 135.24 & 31.93 & -14.19 & 34.46 & & 5.48 & -11.61 & -11.61 \\
\hline
\end{tabular}




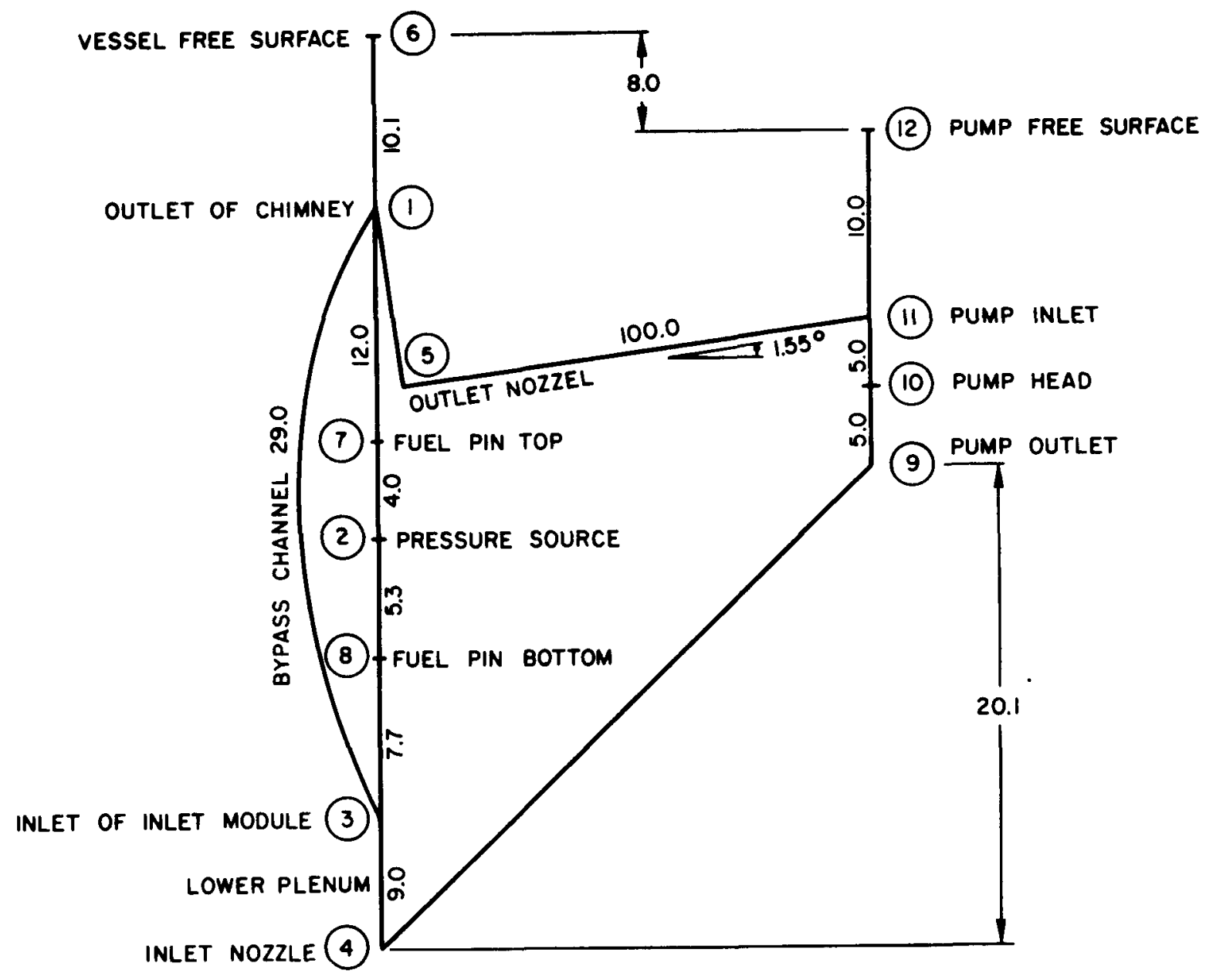

Fig. 1

One dimensional model of the primary system of a CRBR-sized LMFBR used in the analysis of a pressure transient due to boiling in fuel subassemblies. The circled numbers are used to locate junctions. The numbers along the pipes are their lengths in feet. For (a) the loop and (b) the pool systems, the length and inclination to horizontal of the pipe between junctions 4 and 9 are (a) $500.0 \mathrm{ft}$ and $2.304^{\circ}$, and (b) $50.0 \mathrm{ft}$ and $23.7^{\circ}$. 
Distribution for NUREG/CR-1592 (ANL-80-48)

Internal:

$\begin{array}{lll}\text { W. E. Massey } & \text { H. H. Hummel (4) } & \text { D. Weber } \\ \text { E. S. Beckjord } & \text { I. T. Hwang } & \text { H. Wider } \\ \text { C. E. Till } & \text { Kalimullah } & \text { H. M. Domanus } \\ \text { J. B. Wozniak } & \text { M. F. Kennedy } & \text { V. L. Shah } \\ \text { R. Avery } & \text { D. H. Lennox } & \text { B. C-J. Chen } \\ \text { P. B. Abramson } & \text { P. Pizzica } & \text { W. T. Sha } \\ \text { I. Bornstein/ } & \text { F. G. Prohammer } & \text { L. G. LeSage } \\ \text { A. B. Klickman } & \text { D. Rose/A. J. Goldman/ } & \text { P. I. Amundson/ } \\ \text { C. E. Dickerman } & \text { J. F. Marchaterre } & \text { S. G. Carpenter } \\ \text { F. E. Dunn } & \text { R. Sevy } & \text { M. J. Lineberry } \\ \text { D. Ferguson/L. Baker } & \text { J. J. Sienicki } & \text { D. H. Shaftman } \\ \text { S. H. Fistedis } & \text { W. J. Sturm } & \text { A. Travelli } \\ \text { P. L. Garner } & \text { B. J. Toppel } & \text { ANL Contract File } \\ \text { E. Gelbard } & \text { J. B. van Erp } & \text { ANL Libraries (2) } \\ \text { H. Henryson } & & \text { TIS Files (3) }\end{array}$

\section{External :}

USNRC, Washington, for distribution per R7 (380)

DOE-TIC, Oak Ridge (2)

Manager, Chicago Operations and Regional Office, DOE

Chief, Office of Patent Counsel, DOE-CORO

President, Argonne Universities Association, Argonne, I11.

Applied Physics Division Review Committee:

P. W. Dickson, Jr., Westinghouse Electric Corp., 3300 Appel Road, Bethel Park, Pa. 15102

R. L. Hellens, Combustion Engineering Inc., Windsor, Conn. 06095

K. D. Lathrop, Los Alamos Scientific Lab., P. O. Box 1663, Los Alamos, N. M. 87545

W. B. Loewenstein, Electric Power Research Inst., P. O. Box 10412, Palo Alto, Calif. 94303

R. F. Redmond, College of Engineering, The Ohio State Univ., 2070 Neil Ave., Columbus, 0.43210

R. Sher, Dept. Mechanical Eng., Stanford U., Stanford, Calif. 94305

D. B. Wehmeyer, The Detroit Edison Co., 2000 Second Ave., Detroit, Mich. 48226

C. Erdman, U. Virginia, Charlottesville, Va. 22904

K. O. Ott, Purdue U., West Lafayette, Ind. 47906

R. Lancet, Atomics International, P. O. Box 309, Canoga Park, Calif. 91304 